$\begin{array}{lr}\begin{array}{c}\text { Australian Journal of } \\ \text { Crop Science }\end{array} & \text { AJCS } \\ \text { AJCS 14(10):1670-1674 (2020) } & \text { ISSN:1835-2707 }\end{array}$

doi: 10.21475/ajcs.20.14.10.p2550

\title{
Sustainable alternatives for post-harvest strawberry conservation
}

\author{
Léo Omar Duarte Marques*, Jorge Atílio Benati, Josiane Duarte de Carvalho, Paulo Mello-Farias, Tâmara \\ Foster Acosta, Flávio Gilberto Herter, Mateus da Silveira Pasa
}

\author{
Léo Omar Duarte Marques*, Jorge Atílio Benati, Josiane Duarte de Carvalho, Paulo Mello-Farias, Tâmara Foster \\ Acosta, Flavio Gilberto Herter, Mateus da Silveira Pasa
}

Federal University of Pelotas, Capão of Leão Campus, Pelotas, RS, Brazil

*Corresponding author: leodmq@hotmail.com

\begin{abstract}
Strawberries show a short post-harvest conservation period. To improve it, the effect of different post-harvest storage temperatures, conservation methods and three different storage periods were tested on 'San Andreas' strawberry, right after harvest. The experiment consisted of a three factorial $2 \times 5 \times 3$ (temperatures $\times$ methods $\times$ storage periods), arranged in a completely randomized design (CRD). Four replications were used for each treatment, each with five sampling units. The treatments tested were: storage temperatures $-1{ }^{\circ} \mathrm{C}$ and $18^{\circ} \mathrm{C}(\mathrm{T} 1$ and $\mathrm{T} 2)$; conservation methods - sodium hypochlorite $0.5 \%$ (C1), potato starch film $6 \%+$ sodium hypochlorite $0.5 \%$ (C2), cassava starch film $6 \%+$ sodium hypochlorite $0.5 \%$ (C3), UV-C radiation (C4), and control (no treatment) (C5); Storage period - 3, 6, and 9 days (D1, D2, D3, respectively). The parameters assessed were flesh firmness, color (hue angle, chroma, and luminosity), soluble solids (SST) and mass loss. Fruit kept at a temperature of $1^{\circ} \mathrm{C}$ showed better traits than those stored at $18^{\circ} \mathrm{C}$, regardless of the method and storage period. Among the conservation methods tested, only UV-C and sodium hypochlorite improved some attributes (firmness and SST) when associated with refrigeration at $1^{\circ} \mathrm{C}$. The use of potato and cassava starch is not as expected since they do not improve conservation and the total soluble solids contents.
\end{abstract}

Keywords: Fragaria x ananassa; post-harvest, quality, attributes.

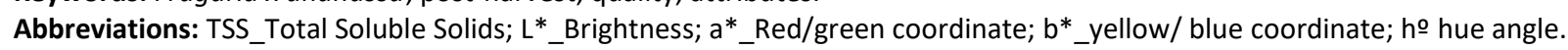

\section{Introduction}

Among the consumed fresh foods, strawberry is pointed out as one of the most difficult to be stored due to the difficulty to keep fruit freshness (Marelli et al., 2016). Because of its high post-harvest perishability, they have high metabolic activity and susceptibility to pathogenic agents causing rots (Malgarim et al., 2006). Strawberries have been used as a model to test storage techniques, since its efficient conservation method indicates a high probability of being applicable to other fruit (Marelli et. al., 2016).

Quality is determined by some attributes, in which color is a very important characteristic for consumers during purchase, where bright fruit and intense color suggest high fruit quality to them (Vargas et al., 2009). Another attribute related to quality is total soluble solids (TSS), and according to Maciel et al. (2004), it is directly linked to fruit flavor, being a trait of easy taste perception and related to maturity and quality, going through intense changes during post-harvest.

According to Sogvar et al. (2015), cooling to low temperatures is the most efficient method to increase fruit lifespan, but other methods associated to this should be studied to improve even more its lifespan. It is mainly used for the most perishable fruit, in order to reduce food waste. The study of edible films has been intensified in the past years. Results found by several researchers have pointed out its use as an important alternative for the fruits, which is difficult to conserve, as minimally processed papaya and strawberries (Tápia et al., 2008; Sogvar et al., 2015). Edible films show high efficiency because they form a physical barrier around the fruit, protecting it against humidity, gases and pathogens that could affect its quality (Sogvar et al., 2015). Beside that, starch based films are edible, transparent, odorless, tasteless, and colorless, which are very interesting characteristics for food packing (Bersaneti, 2016).

Among the techniques that have been gaining space to potentialize post-harvest fruit lifespan, the use of $C$ ultraviolet (UV-C) is one of them. This method consists of eliminating micro-organisms from vegetal tissue through the antimicrobial effect caused by radiation (Acosta et al., 2018). In this sense, the elimination or reduction of pathogens incidence and their structures in fruit tissues will keep its sensorial attributes and lifespan longer (Acosta et al., 2018). Chlorine is widely used in fruit sanitization, mainly in the form of sodium hypochlorite. It acts on eliminating the undesirable organisms, resulting in a longer fruit lifespan (Nascimento and Silva, 2010). 
The need of producing safer food and minimizing the use of fungicides and other high toxicity products intensifies the necessity to study and discuss sustainable fruit conservation techniques in depth. The present research aims to evaluate the efficiency of sustainable methods for post-harvest conservation of strawberry cultivar San Andreas.

\section{Results}

\section{Flesh Firmness}

Flesh firmness showed reduction regardless of the method and temperature during conservation. The storage period did not depend on them for the firmness parameter (Figure 1).

Fruit kept at a temperature of $1^{\circ} \mathrm{C}$ differed from the others in practically all data, and in the last period (9 days), all the conservation methods stored at $1^{\circ} \mathrm{C}$ showed firmer flesh (Table 1), compared to those stored at $18^{\circ} \mathrm{C}$. The methods used in association with temperature of $1^{\circ} \mathrm{C}$ differed among them only nine days after harvest. However, the UV-C radiation method presented greater fruit firmness, while cassava starch $6 \%+$ sodium hypochlorite $0.5 \%$ showed the lowest means.

\section{Total soluble solids}

Evaluation of amount of total soluble solids ( ${ }^{\circ}$ Brix) showed all treatments kept at a temperature of $1^{\circ} \mathrm{C}$ differed positively in all analysis, pointing to the efficiency of low temperatures usage to maintain fruit flavor. Analyzing the results for ${ }^{\circ}$ Brix (fruit kept at a temperature of $1^{\circ} \mathrm{C}$ ), we noticed that sodium hypochlorite $0.5 \%$ differed positively in fruits that showed lower ${ }^{\circ}$ Brix levels (Table 2 ).

\section{Mass loss}

In the mass loss parameter, fruits kept at a temperature of $1^{\circ} \mathrm{C}$ differed from those kept at a temperature of $18^{\circ} \mathrm{C}$, in which they always showed lower values (Table 3 ). The most intense mass loss was occurred in fruits kept at $18^{\circ} \mathrm{C}$, while for the one kept at $1^{\circ} \mathrm{C}$, the used methods differed significantly only during six days storage.

\section{Hue angle}

The hue angle, parameter that determines fruit color, points that the values closest to 30 would indicate reddish fruit. However, higher values indicate that fruits are losing color, due to poor conservation. It was seen that fruit differed between the last evaluation date (nine days after harvest), when kept at $1^{\circ} \mathrm{C}$. They were able to maintain coloration closer to red at all evaluation dates. Among the fruit kept at $18^{\circ} \mathrm{C}$, differences were found only at 9 days of storage, where it was treated with potato starch. The UV-C showed lower hue angles than the other treatments, having a more reddish color (Table 4). For fruits kept at $1^{\circ} \mathrm{C}$, all methods showed similar efficiency, keeping their reddish color.

\section{Chroma}

Chroma is a parameter that points directly to color purity. Fruit with a high chroma value shows more uniform coloration. In this sense, chroma values found in the present research indicated that fruits kept at $1^{\circ} \mathrm{C}$ in some treatments have more uniform coloration at 3 and 6 days after harvest and in all treatments at 9 days after harvest (Table 5). When fruits were stored at $1^{\circ} \mathrm{C}$, we observed the most homogeneous colorations on fruits exposed to the UV-C method. Fruit exposed to sodium hypochlorite and only refrigerated at $1^{\circ} \mathrm{C}$ also showed uniform coloration, not differing from UV-C radiation. However, they did not differ from fruits submitted to potato starch $6 \%$ method + sodium hypochlorite $0.5 \%$ and cassava starch $6 \%+$ sodium hypochlorite $0.5 \%$, which showed less uniform coloration.

\section{Luminosity}

The luminosity parameter, which indicates fruit brightness, showed differences only in the first evaluation (Table 6), three days after harvest. Fruits that were exposed to cassava starch $6 \%+$ sodium hypochlorite $0.5 \%$ and sodium hypochlorite $0.5 \%$ methods showed brighter fruit. However, they did not differ from potato starch $6 \%+$ sodium hypochlorite. As the days passed, the brightness between the different methods was similar.

\section{Discussion}

According to Brackmann et al. (2011), firmness values above $5.20 \mathrm{~N}$ could be acceptable for commercialization. In this sense, all methods used in association with temperature of $1^{\circ} \mathrm{C}$ were efficient for this parameter in all storage periods. The method that showed the lowest firmness means was potato starch + sodium hypochlorite $0.5 \%$, with average flesh firmness value of $5.53 \mathrm{~N}$, in the last evaluation date, being within the commercialization standards.

Trevisan et al. (2017) and Cantillano et al. (2008) indicated a minimum value of $6.0^{\circ}$ Brix as ideal for flavor quality in strawberry fruit. In the present study, only fruits, at nine days after harvest and kept at a temperature of $1^{\circ} \mathrm{C}$, reached this ${ }^{\circ}$ Brix value. Fruit exposed to potato starch $6 \%+$ sodium hypochlorite $0.5 \%$ and potato starch $6 \%+$ sodium hypochlorite $0.5 \%$ showed values lower than $6.0^{\circ}$ Brix. The probable hypothesis is that the edible film interacted with the fruit, reducing ${ }^{\circ}$ Brix and changing the fruit flavor. In this way, the use of cassava starch and potato for strawberry fruit conservation is not interesting, because there is a considerable loss of fruit flavor quality.

Fruits from cultivar San Andreas showed greater mass loss compared to Camarosa, in experiments performed under refrigeration. Tibola et al. (2007) found values between $0.94 \%$ and $1.87 \%$ of mass loss 10 days after harvest, while, in the present research, fruit mass loss kept at $1^{\circ} \mathrm{C}$ at nine days varied between $1.90 \%$ and $4.58 \%$. The temperature used by Tibola et al. (2007) was $0.5^{\circ} \mathrm{C}$, half degree lower than the present study, in which it is probably due to less difference between the storage temperatures. According to Cantillano (2003), the maximum acceptable mass loss for strawberries is $6 \%$, to prevent fruit external appearance depreciation. According to Silva et al. (2014), reddish fruit change skin color as they deteriorate, showing greater hue angle values. In the present research we observed that fruits kept at $18^{\circ} \mathrm{C}$ have high color changes along the other treatents.

It is important to keep strawberry fruit refrigerated in lower temperatures $\left(1^{\circ} \mathrm{C}\right)$ because, at higher temperatures $\left(18^{\circ} \mathrm{C}\right)$, it shows considerable loss of physical-chemical characteristics. Among all sustainable methods used, the most indicated ones, which show similar efficiency, are: sodium hypochlorite $0.5 \%$, UV-C radiation or refrigeration at $1^{\circ} \mathrm{C}$. The use of potato and cassava starch showed to be 
Table 1. Influence of different conservation methods and temperature on flesh firmness (Newton) of 'San Andreas' strawberry fruits.

\begin{tabular}{|c|c|c|c|c|c|c|}
\hline \multirow{3}{*}{ Method } & \multicolumn{2}{|l|}{3 days } & \multicolumn{2}{|l|}{6 days } & \multicolumn{2}{|l|}{9 days } \\
\hline & \multicolumn{6}{|c|}{ Storage temperature } \\
\hline & $1^{\circ} \mathrm{C}$ & $18^{\circ} \mathrm{C}$ & $1^{\circ} \mathrm{C}$ & $18^{\circ} \mathrm{C}$ & $1^{\circ} \mathrm{C}$ & $18^{\circ} \mathrm{C}$ \\
\hline Hypoclorite & $9.17 \mathrm{~A}$ & $4.64 \mathrm{~B}$ & $9.84 \mathrm{~A}$ & $3.14 \mathrm{~B}$ & $6.49 \mathrm{ab} A$ & $2.85^{\mathrm{ns}} \mathrm{B}$ \\
\hline $\begin{array}{l}\text { Potato starch + } \\
\text { hipocloryte }\end{array}$ & $9.45 \mathrm{~A}$ & $4.99 \mathrm{~B}$ & $7.86 \mathrm{~A}$ & $2.91 \mathrm{~B}$ & $5.53 \mathrm{bA}$ & $1.53 \mathrm{~B}$ \\
\hline $\begin{array}{l}\text { Cassava starch + } \\
\text { hipocloryte }\end{array}$ & $10.61 \mathrm{~A}$ & $4.86 \mathrm{~B}$ & $9.13^{\mathrm{NS}}$ & $4.78^{\mathrm{NS}}$ & $8.46 \mathrm{ab} A$ & $3.53 \mathrm{~B}$ \\
\hline UV-C & $10.43 \mathrm{~A}$ & $4.64 B$ & $9.58 \mathrm{~A}$ & $2.95 \mathrm{~B}$ & 9.70 a $A$ & $2.31 \mathrm{~B}$ \\
\hline Control & $11.78 \mathrm{~A}$ & $3.38 \mathrm{~B}$ & $9.24 \mathrm{~A}$ & $2.58 \mathrm{~B}$ & $8.49 \mathrm{ab} A$ & $2.67 B$ \\
\hline
\end{tabular}

Means followed by small case letters in the column, and upper-case letters in the row do not statistically differ at 5\% probability using Tukey's test. ns - not significant at $5 \%$ Tukey's test.

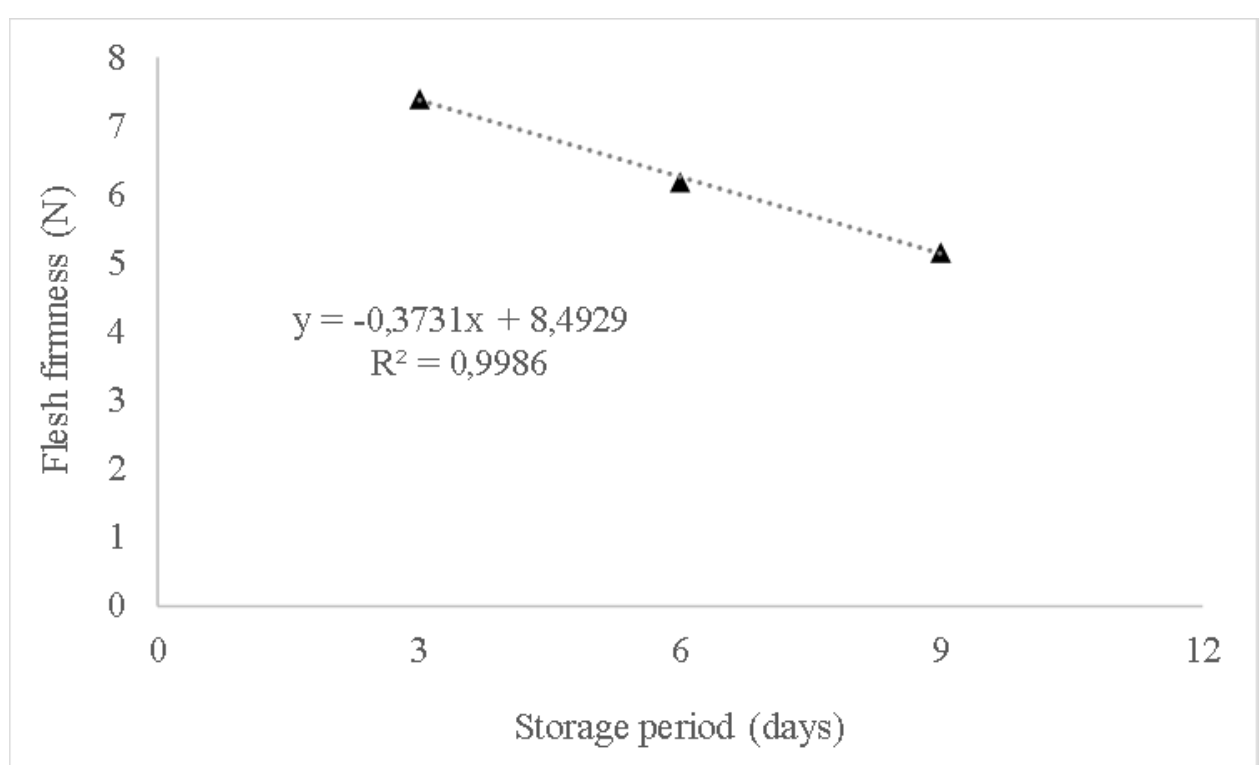

Fig 1. Firmness (Newtons) of 'San Andreas' strawberry fruits at 3, 6 and 9 days of storage.

Table 2. Influence of different conservation methods and temperatures in the total soluble solids content (TSS; $\left.{ }^{\circ} \mathrm{Brix}\right)$ of 'San Andreas' strawberry fruits.

\begin{tabular}{|c|c|c|c|c|c|c|}
\hline \multirow{3}{*}{ Method } & \multicolumn{2}{|l|}{3 days } & \multicolumn{2}{|l|}{6 days } & \multicolumn{2}{|l|}{9 days } \\
\hline & \multicolumn{6}{|c|}{ Storage temperature } \\
\hline & $1^{\circ} \mathrm{C}$ & $18^{\circ} \mathrm{C}$ & $1^{\circ} \mathrm{C}$ & $18^{\circ} \mathrm{C}$ & $1^{\circ} \mathrm{C}$ & $18^{\circ} \mathrm{C}$ \\
\hline Hipoclorite & 7.75 a $A$ & $5.20^{\mathrm{ns}} \mathrm{B}$ & 7.30 a $A$ & 4.97 a B & 6.92 a $A$ & 4.45 a B \\
\hline $\begin{array}{l}\text { Potato starch + } \\
\text { hipoclorite }\end{array}$ & $5.87 \mathrm{~b} \mathrm{~A}$ & $4.37 \mathrm{~B}$ & 5.52 с A & 3.72 b B & $5.25 \mathrm{c} \mathrm{A}$ & $2.62 \mathrm{~b} \mathrm{~B}$ \\
\hline $\begin{array}{l}\text { Cassava starch + } \\
\text { hipoclorite }\end{array}$ & $5.72 \mathrm{~b} \mathrm{~A}$ & $4.20 \mathrm{~B}$ & $5.82 \mathrm{bc} \mathrm{A}$ & 4.97 a B & 5.72 bc A & 4.25 a B \\
\hline UV-C & 7.07 a A & $5.57 \mathrm{~B}$ & 7.57 a A & $4.75 \mathrm{ab} B$ & 7.22 a A & 4.10 a B \\
\hline Control & 6.97 a A & $5.02 \mathrm{~B}$ & $6.57 \mathrm{ab} A$ & $4.50 \mathrm{ab} B$ & $6.62 \mathrm{ab} A$ & 4.05 a B \\
\hline
\end{tabular}

Table 3. Influence of different conservation methods and temperature in the mass loss (\%) of 'San Andreas' strawberry fruits.

\begin{tabular}{|c|c|c|c|c|c|c|}
\hline \multirow{3}{*}{ Method } & 3 days & & 6 days & & 9 days & \\
\hline & \multicolumn{6}{|c|}{ Storage temperature } \\
\hline & $1^{\circ} \mathrm{C}$ & $18^{\circ} \mathrm{C}$ & $1^{\circ} \mathrm{C}$ & $18^{\circ} \mathrm{C}$ & $1^{\circ} \mathrm{C}$ & $18^{\circ} \mathrm{C}$ \\
\hline Hipoclorite & $1.23^{\mathrm{ns} N S}$ & 8.25 & $0.41 b^{\mathrm{NS}}$ & $3.7 c^{\mathrm{NS}}$ & $4.58^{\mathrm{NS}}$ & $10.01 a^{N S}$ \\
\hline $\begin{array}{l}\text { Potato starch + } \\
\text { hipoclorite }\end{array}$ & 4.91 & 1.73 & $2.97 b^{N S}$ & $8.67 b c^{\text {NS }}$ & $2.85^{\mathrm{ns}} \mathrm{B}$ & $10.95 \mathrm{ab} \mathrm{A}$ \\
\hline $\begin{array}{l}\text { Cassava starch + } \\
\text { hipoclorite }\end{array}$ & 0.51 & 3.09 & $3.23 b^{\mathrm{NS}}$ & $2.51 c^{N S}$ & $3.09^{\text {ns NS }}$ & $3.99 b^{N S}$ \\
\hline UV-C & 1.91 & 8.21 & 10.98 a B & 20.26 a A & $2.24^{\mathrm{ns}} \mathrm{B}$ & 18.77 a A \\
\hline Control & 0.41 & 2.71 & 1.17 b B & $16.40 \mathrm{ab} A$ & $1.90^{\mathrm{ns}} \mathrm{B}$ & 17.40 a A \\
\hline
\end{tabular}


Table 4. Influence of different conservation methods and temperature in Hue angle of 'San Andreas' strawberry fruits.

\begin{tabular}{|c|c|c|c|c|c|c|}
\hline \multirow{3}{*}{ Método } & 3 days & & 6 days & & 9 days & \\
\hline & \multicolumn{6}{|c|}{ Storage temperature } \\
\hline & $1^{\circ} \mathrm{C}$ & $18^{\circ} \mathrm{C}$ & $1^{\circ} \mathrm{C}$ & $18^{\circ} \mathrm{C}$ & $1^{\circ} \mathrm{C}$ & $18^{\circ} \mathrm{C}$ \\
\hline Hypochlorite & $37.48^{\mathrm{ns}}$ & $34.16^{\mathrm{ns}}$ & 37.31 & 45.02 & $37.35^{\mathrm{ns}} \mathrm{B}$ & 82.20 a A \\
\hline $\begin{array}{l}\text { Potato starch + } \\
\text { hypochlorite }\end{array}$ & 34.21 & 37.31 & 33.17 & 36.83 & $36.85^{\text {NS }}$ & $48.15 \mathrm{c}$ \\
\hline $\begin{array}{l}\text { Cassava starch + } \\
\text { hypoclorite }\end{array}$ & 35.68 & 38.54 & 37.10 & 45.40 & 39.96 B & $58.30 \mathrm{bc} \mathrm{A}$ \\
\hline UV-C & 36.93 & 37.86 & 35.39 & 38.46 & $35.86 \mathrm{~B}$ & $54.00 \mathrm{cA}$ \\
\hline Control & 36.30 & 36.98 & 32.80 & 45.09 & $34.76 \mathrm{~B}$ & $69.74 \mathrm{ab} A$ \\
\hline
\end{tabular}

Table 5. Influence of different conservation methods and temperatures in the chroma of 'San Andreas' strawberry fruits.

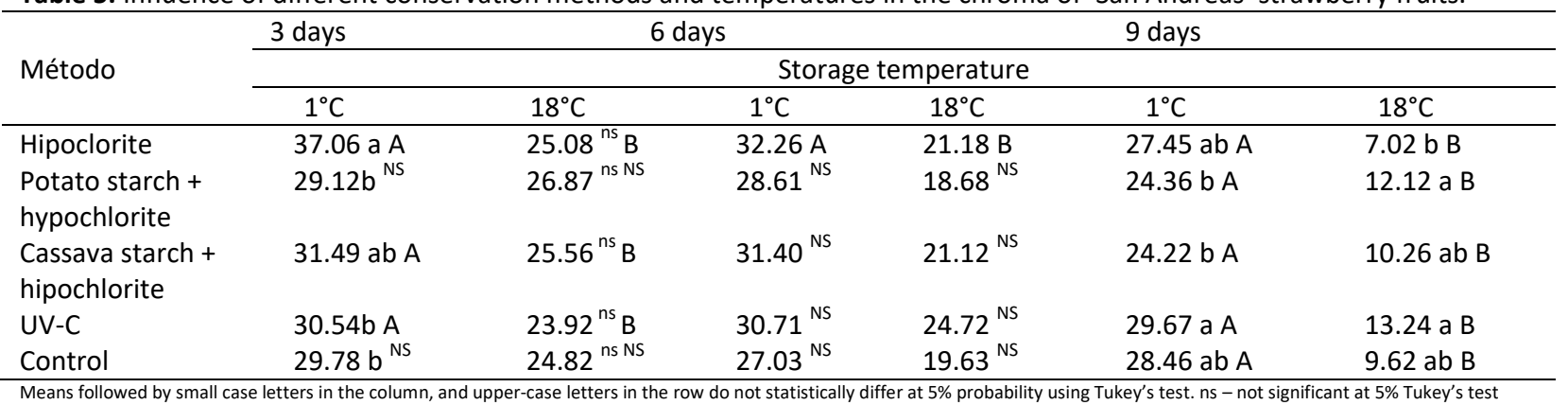

Table 6. Influence of different conservation methods and temperature in the luminosity of 'San Andreas' strawberry fruits

\begin{tabular}{|c|c|c|c|c|c|c|}
\hline \multirow{3}{*}{ Method } & 3 days & & & & ays & \\
\hline & \multicolumn{6}{|c|}{ Storage temperature } \\
\hline & $1^{\circ} \mathrm{C}$ & $18^{\circ} \mathrm{C}$ & $1^{\circ} \mathrm{C}$ & $18^{\circ} \mathrm{C}$ & $1^{\circ} \mathrm{C}$ & $18^{\circ} \mathrm{C}$ \\
\hline Hypoclorite & $33.91 \mathrm{a}$ & $27.93^{\mathrm{ns}}$ & 29.35 & 34.67 & $27.49^{\text {NS }}$ & $29.25 b$ \\
\hline $\begin{array}{l}\text { Potato Starch + } \\
\text { hipoclorite. }\end{array}$ & $31.26 \mathrm{ab}$ & 27.93 & 29.67 & 30.72 & $27.56^{N S}$ & $31.97 \mathrm{ab}$ \\
\hline $\begin{array}{l}\text { Cassava starch + } \\
\text { hypoclorite }\end{array}$ & $31.63 \mathrm{a}$ & 28.73 & 30.07 & 31.98 & $24.94^{\mathrm{NS}}$ & $29.60 \mathrm{~b}$ \\
\hline UV-C & $25.33 \mathrm{bc}$ & 26.72 & 28.05 & 33.67 & $28.52^{\mathrm{NS}}$ & $31.54 \mathrm{ab}$ \\
\hline Control & 24.01 c & 29.52 & 29.65 & 26.48 & 27.54 B & 36.82 a $A$ \\
\hline
\end{tabular}

Means followed by low case letters in the column and upper-case letters in the row do not statistically differ at the level of $5 \%$ of probability by Tukey's test. ns - not significant at $5 \%$ probability by Tukey's test.

Inefficient; and therefore, not being indicated, because they interact with the fruit, changing the amount of total soluble solids ('Brix) and fruit flavor. Finally, we concluded that fruits kept during the storage period at temperature of 1 으 show the best physical-chemical characteristics when compared to fruits stored at a temperature of $18^{\circ} \mathrm{C}$. Edible films methods (potato and cassava starch) reduce the total soluble solids without influencing positively other parameters. Thus, they are not considered interesting alternatives in strawberry conservation. Regardless the methods used, the post-harvest conservation at $1^{\circ} \mathrm{C}$ is the most efficient one to keep strawberries fresher.

\section{Materials and methods}

\section{Plant materials and experimental site}

The research was developed in November 2018, with fresh strawberries (Fragaria $\times$ ananassa) cultivar 'San Andreas. Fruits were obtained right after harvest from a grower in Pelotas, RS, Brazil. After that, they were taken to the Fruit Science laboratory at Federal University of Pelotas.

\section{Experimental design}

The experiment was arranged in a completely randomized design (CRD), as a three factorial $2 \times 5 \times 3$ (temperatures $x$ methods $x$ storage periods), totalizing 30 treatments. Four replications were used for each treatment, each one with five sampling units, consisted of one fruit. The temperature treatments were to submit the fruit in chambers with constant temperature of $1^{\circ} \mathrm{C}$ to refrigerate it and temperature of $18^{\circ} \mathrm{C}$ to evaluate the performance of the methods in higher temperature. The methods used were edible films (potato starch $6 \%$ and cassava starch 6\%) associated with sodium hypochlorite $0.5 \%$, only sodium hypochlorite, UV-C radiation and control (no treatment). The storage period was the third factor, being three, six, and nine days.

Treatments consisted of storage temperatures $\left(\mathrm{T} 1: 1^{\circ} \mathrm{C} ; \mathrm{T} 2\right.$ : $18{ }^{\circ} \mathrm{C}$ ), conservation methods [C1: sodium hypochlorite $0.5 \%$; C2: potato starch $6 \%+$ sodium hypochlorite $0.5 \%$; C3: cassava starch $6 \%$, + sodium hypochlorite $0.5 \%$; C4: UV-C radiation; and $\mathrm{C} 5$ : control (no treatment)], storage period (D1: 3 days; D2: 6 days; and D3: 9 days). Then, by the combination of these factors, the following treatments were formed: (T1 x C1 x D1), (T1 x C1 x D2), (T1 x C1 x D3), (T1 x C2 $x$ D1), (T1 x C2 x D2), (T1 x C2 x D3), (T1 x C3 x D1), (T1 x C3 x 
D2), (T1 x C3 x D3), (T1 x C4 x D1), (T1 x C4 x D2), (T1 x C4 D3), (T1 $x$ C5 $\times$ D1), (T1 $\times$ C5 $\times$ D2), (T1 $\times$ C5 $\times$ D3), $(T 2 \times C 1 \times$ D1), (T2 x C1 x D2), (T2 x C1 x D3), (T2 x C2 x D1), (T2 x C2 D2), (T2 $\times$ C2 $\times$ D3), $(\mathrm{T} 2 \times \mathrm{C} 3 \times \mathrm{D} 1),(\mathrm{T} 2 \times \mathrm{C} 3 \times \mathrm{D} 2),(\mathrm{T} 2 \times \mathrm{C} 3 \times$ D3), (T2 $\times$ C4 $\times$ D1), $(T 2 \times C 4 \times D 2),(T 2 \times C 4 \times D 3),(T 2 \times C 5 \times$ $\mathrm{D} 1),(\mathrm{T} 2 \times \mathrm{C} 5 \times \mathrm{D} 2)$ e $(\mathrm{T} 2 \times \mathrm{C} 5 \times \mathrm{D} 3)$.

\section{Physicochemical analysis}

The samples exposed to sodium hypochlorite were immersed in a tray with water and sodium hypochlorite at $0.5 \%$ for three minutes. Then they were placed to drain the excess of liquid at room temperature. After that, the methods were applied. When the treatment consisted only in applying sodium hypochlorite at $0.5 \%$, the samples were taken to the refrigerated chamber at $1^{\circ} \mathrm{C}$, or to the chamber at $18^{\circ} \mathrm{C}$, according to treatment.

The potato and cassava starch were placed separately in beakers of 3.0 liters and warmed to a maximum temperature of $70 \circ \mathrm{C}$ with constant agitation until starch gelling, which happened in approximately 20 minutes. After gelling, starch was kept resting until completing cooling at room temperature. Then, the fruits were immersed during 2 minutes in the starch treatments and placed in plastic trays to drain the excess of liquid. They were stored at $1^{\circ} \mathrm{C}$ or $18^{\circ} \mathrm{C}$, according to treatment. Fruits exposed to UV-C radiation were exposed to a UV-C lamp, inside an ultraviolet irradiator for 2 minutes. The samples were kept at $15 \mathrm{~cm}$ from the lamp, and fruits were stored at $1^{\circ} \mathrm{C}$ or $18^{\circ} \mathrm{C}$, according to treatment.

The first assessed parameter was fruit color: performed with a Minolta colorimeter CR-300, with D65 light source in two positions of each fruit and in all fruit replications, reading the coordinates $L^{*}$, which indicates luminosity (black and white variation), $a^{*}$ (indicates variation from green to red) and $b^{*}$ (variation from blue to yellow). With the values $a^{*}$ and $b^{*}$, the hue angle was calculated $\left[h^{\circ}=\tan ^{-1}\left(b^{*} / a^{*}\right)\right]$ which defines color tint and chroma $\left(c=\sqrt{(a *)^{2}+(b *)^{2}}\right)$, or color intensity.

The second assessed parameter was fruit firmness: measured with a manual penetrometer, with a $6 \mathrm{~mm}$ tip, in the equatorial fruit region, expressed in Newtons (N).

Next, total soluble solids (TSS) obtained with a digital refractometer Atago, expressed as juice -Brix.

And finally, mass loss obtained through the comparison between initial and final weight, expressed in \%. The evaluations were performed at 3, 6 and 9 days after fruit harvest.

\section{Data Analysis}

The statistical analysis was performed using the Statistical Analysis System (SAS Studio) software. Variance analysis (ANOVA) was done by $F$ test. When interaction was significant, Tukey's test was verified, at 5\% significance level for the qualitative parameters. Regression analysis was performed for the flesh firmness parameter.

\section{Conclusions}

Fruits kept during post-harvest storage at 1 o $\mathrm{C}$ have better physicochemical characteristics, when compared to fruits stored at $18 \stackrel{\circ}{ } \mathrm{C}$.
The highest efficiency for the analyzed variables were UV-C radiation, $0.5 \%$ sodium hypochlorite and storage at $1^{\circ} \mathrm{C}$ without the application of any product.

Edible film methods reduced the soluble solids content of strawberry fruits.

\section{Acknowledgments}

The authors wish to thank the National Council for Scientific and Technological Development (CNPq), the Coordination of Improvement of Higher Education Personnel (CAPES) and Federal University of Pelotas for the support.

\section{References}

Acosta TA, Marques, LOD, Nardello I, Navroski R, Mello-Farias PC (2018) Ultraviolet-C Radiation on Psidium cattleyanum L. Conservation and Its Influence on Physicochemical Fruit Characteristics. J Exp Agric Int. 6: 1-7.

Bersaneti GT, Mantovan J, Magri A, Mali S, Celligoi MAPC (2016) Edible films based on cassava starch and fructooligosaccharides produced by Bacillus subtilis natto CCT 7712. Carbohyd Polym. 151: 1132-1138.

Brackmann A, Pavanello EP, Both V, Janisch DI, Schmitt OJ, Giménez $G$ (2011) Avaliação de genótipos de morango quanto à qualidade e potencial de armazenamento. Revista Ceres. 58(5): 542-547.

Cantillano RF (2008) Qualidade físico-química e sensorial de cultivares de morangueiro durante $o$ armazenamento refrigerado. Pelotas: Embrapa Clima Temperado, 29 p. (Embrapa Clima Temperado. Boletim de Pesquisa e Desenvolvimento, 75).

Cantillano RF (2003) Colheita e pós-colheita. In: Santos AM \& Medeiros ARM (Ed.). Morango: produção. Brasília, EMBRAPA,.6874. (Frutas do Brasil, 40).

Maciel MIS, Lima VLAG, Santos ES, Lima MS (2004) Effects of biofilm and refrigeration on acerola postharvest conservation. Rev Bras Frutic. 26(1): 168-170.

Malgarim MB, Cantillano RFF, Coutinho EF (2006) Systems and conditions of harvest and storage in strawberries CV's 'Camarosa' quality. Rev Bras Frutic. 28(2): 185-189.

Marelli B, Brenckle MA, Kaplan DL, Omenetto FG (2016) Silk fibroin as edible coating for perishable food preservation. Sci rep-uk. 6: 25263.

Nascimento MS, Silva N (2010) Tratamentos químicos na sanitização de morango (Fragaria vesca L.). Braz J Food Tec. 13(1): 11-7.

Tapia MS, Rojas-Grau MA, Carmona A, Rodríguez FJ, Soliva-Fortuny R, Martin-Belloso O (2008) Use of alginate-and gallant-based coatings for improving barrier, texture and nutritional properties of fresh-cut papaya. Food Hydrocolloid. 22(8): 1493-1503.

Tibola CS, Malgarim MB, Zaicovski CB, Pegoraro C, Cero J, Ferri VC (2007) Luz ultravioleta na inibição de podridões pós-colheita de morangos (Fragaria ananassa, Duch.) 'Camarosa'. Rev Bras AgroCiência. 13(4): 509-512.

Trevisan F, Madruga-Lima CS, Zanella-Pinto V (2017) Ácido Salicílico no desenvolvimento de plantas e nas caracteristicas físicoquímicas de frutas de morango "Milsei-Tudla". Rev Iberoam Tec Postcosecha. 18(2): 106-114.

Silva AS, Queiroz DM, Pinto FAC, Santos NT (2014) Coffee quality and its relationship with Brix degree and colorimetric information of coffee cherries. Precis Agric. 15(5): 543-554.

Sogvar OB, Saba MK, Emamifar A (2016) Aloe Vera and ascorbic acid coatings maintain postharvest quality and reduce microbial load of strawberry fruit. Postharvest Biol Tec. 114: 29-35.

Vargas M, Chiralt A, Albors A, González-Martínez C (2009) Effect of chitosan-based edible coatings applied by vacuum impregnation on quality preservation of fresh-cut carrot. Postharvest Biol Tec. 51(2): 263-271. 